\title{
He Said / She Said: Personal Narratives on Same-Sex Marriage
}

\author{
John D. MacBride and Tracey Rickards
}

John MacBride completed his Masters of Education at Brock University in 2000 and is currently a professor in the Faculty of Business at Seneca College in Toronto. Here, he teaches marketing. personnel, retail theory, advertising, computer graphics, drawing, retail interior design, and the history of design. John's research interests include the development of new curricula that incorporate Web technology and mobile learning experiences for students, the application of Web technology to portfolios, and the implications of this for learning and development. He is also a practicing artist with work both in private and in public collections.

Tracey Rickards graduated from the University of New Brunswick, Faculty of Nursing in 1986, worked in Toronto for four years, and in 1990 moved back to Fredericton where she lives with her partner and their four children. She is currently pursuing her M.A. that focuses on the experiences of women coming out later in life. She is interested in understanding what factors contribute to the delayed acknowledgment of sexual orientation. In 2003, Rickards received the Chris Landry Memorial Scholarship, a Lambda Foundation for Excellence award for her research on lesbian health care issues.

A t no time in Canadian history has the battle for same-sex marriage been a hotter topic. Recent legal challenges to the federal definition of marriage have resulted in equal recognition for gays and lesbians in the institution of matrimony (see EGALE). Many gays and lesbians took to the streets on Pride Day 2003 to celebrate their newfound rights and freedoms (Galloway). Yet not all members of the gay and lesbian communities welcome the right to marry. Victor Dwyer states that our pursuit of heterosexual institutions like marriage and adoption have taken the fun, and the fire out of being gay. After all, was not the plan of 'gay 
liberation,' as it was called not so long ago, to forge an exciting new world different from the world of straights? This new world was to bear the stamp of those brave queers, transvestites, and street kids who pelted raiding police with rocks and high heels at New York's Stonewall Inn in 1969, thereby launching the modern gay-rights movement. Are we not the same ones who, in 1981, marched hundreds strong through the streets of Toronto following raids on the city's gay bathhouses - and the largest mass arrests in Canada since the FLQ crisis - demanding our right to have anonymous sex when and where we felt like it? (42).

Certainly, the issue of same-sex marriage has threatened to divide the gay community. Andrew Sullivan argues:

The gay movement has ducked this issue primarily out of fear of division. Much of the gay leadership clings to notions of gay life as essentially outsider, anti-bourgeois, radical. Marriage, for them, is co-optation into straight society. For the Stonewall generation, it is hard to see how this vision of conflict will ever fundamentally change. But for many other gays - my guess, a majority - while they don't deny the importance of rebellion 20 years ago and are grateful for what was done, there's now the sense of a new opportunity. A need to rebel has quietly ceded to a desire to belong. To be gay and to be bourgeois no longer seems such an absurd proposition. (Par. 8)

William Tierney argues that Sullivan takes an assimilationist perspective: an argument that assumes we must convince the majority that gays and lesbians are no different than they are, entitled to the same rights under the law. While Tierney does agrees with Sullivan about equal rights, he offers a cautionary note about assuming that we are all the same:

Is there any evidence that groups who are discriminated against have a better chance to lessen their stigma and attain their rights if they act as the mainstream does? ... If similarities are to be accepted as a cultural good, does it mean that I ought to strive to erase from myself any differences from the norm? And again, rather than simply desiring to finagle an invitation to the table, should we not be more concerned about who's handing out the invitations and what we have to do to get invited? (50) 
For gays and lesbians wishing to marry, there remain many questions. Why would we want to participate in a ritual that is coined by some as an ancient and disreputable heterosexual institution? Will same-sex marriages carry the same responsibilities (and possible encumbrances) as heterosexual marriages? Will we negotiate an improved definition of marriage for ourselves that can be supported by our entire community? Will same-sex marriage stratify our community even further? The following narratives chronicle the experiences of two couples, one gay and one lesbian, who had samesex commitment ceremonies prior to the recent successful court challenges. In these personal narratives, the authors address how and why they proceeded down the aisle, despite any legal recognition of their ceremonies. They also address how their 'marriages' affected their family and friends. These stories attempt to capture their motivation, memories, and mishaps in their quest to marry.

\section{He Said}

In June 1999, I married my partner in a same-sex commitment ceremony on national television. It was nonetheless an 'intimate little affair' involving about 65 of our closest friends and family. The decision to get married brought with it many reactions - both positive and negative - from our friends, family, and the community at large.

I had proposed to Corry, my partner, about a year earlier while we were visiting friends in Montréal. We discussed at length our reasons for wanting to get married. They included a desire to have our community support and stand up for our relationship: to give it the same recognition and legitimacy that heterosexual couples enjoy. We also wanted to get married in order to publicly express our love and commitment to each other. Weddings are an opportunity to celebrate a relationship and we wanted to take full advantage of the opportunity.

They say weddings bring out the best and the worst in people, and ours was no exception. Our close friends rallied round, volunteering to do everything including catering the dinner, drafting speeches, making corsages, and organizing separate stags. One friend insisted on becoming our 'bridal registry' (against our objections). We were not in this for the gifts, although I must say they were 
fabulous. We found ourselves in the enviable position of having to turn down offers of help.

But other reactions were not so positive. We found ourselves having to explain to our families why we wanted to get married (we feel quite comfortable using the term regardless of its legality). The invitation sparked a number of unexpected reactions. Corry's brother and his sister-in-law needed to have a phone conversation with us about why we were getting married and what the service would look like. We avoided the temptation to tell them it was a nude ceremony where we would all pop 'e' at the end. Corry's parents wrote us a lovely letter explaining why they could not attend due to religious reasons. My father met with us to tell us that although he was happy we were together, he felt he could not attend on principle. My mother, annoyed with my father, attended on her own. My brother and his wife never responded to the invitation, prompting me to contact them for an answer. Their response was an uncomfortable, "We don't think so."

The national television experience came when we discovered that the Life Network was looking for a same-sex couple for their Weddings series. We talked about why we would want to air our vows through such a public venue. In the end, we felt that the visibility could provide some good for people struggling with the same issue. We contacted the producer, Karen Wooley, and set up a screen test. We were a bit surprised when Karen later contacted us to say we would be the first same-sex wedding on their series.

When the show finally aired in July 1999 (Wooley), reaction to it was extremely positive and quite unexpected. The very next day, people started stopping us on the street to congratulate us. Two little old ladies chased Corry across the Toronto Eaton Centre in an attempt to wish him well. People we had not seen in years sent us emails and notes of congratulations. We were caught off guard by the exposure that the episode gave us: we never imagined that so many people actually watched this show. To complicate matters, the episode continues to air unabatedly in reruns. Karen finally admitted to us that it is one of their more popular episodes.

Our getting married did result in a shift in our friends' and families' attitudes toward us. While they were always supportive of our relationship, they now treat us as a family unit, something permanent and fixed. Interestingly enough, my father, despite his objections to the marriage, began to treat Corry as a son-in-law. 
There was also some negative fallout. Many of our straight friends tried to transplant their view of heterosexual marriage onto our relationship. (I sometimes wonder if they were trying to figure out which one of us was the wife.) They seemed concerned if one of us went somewhere without the other. (I promised to love and support Corry forever, not be joined to him at the hip.) They frowned if we seemed too familiar with other men. (God forbid you ever broach the subject of nonmonogamy with them!) These issues seem to have faded as they have watched our relationship grow and flourish.

The same cannot be said of the gay community at large. There are many people in the gay community who view long-term gay relationships with an air of suspicion. A year after our wedding, Corry was accosted in a gay bar while out with friends. He was asked in a snide tone, "Where is your partner? Is it over already?" There are others who feel we are caving in by engaging in so-called antiquated heterosexual rituals. While they are more than entitled to their opinions, I do not feel I need to be lectured to while out for the evening with friends.

Most of the positive comments we received came from women, both lesbian and straight. The few snide comments we received came from gay men.

The most negative reaction we received was a series of harassing and threatening phone calls. During the first wave of reruns, we began to get calls in the middle of the night threatening us with violence. The police suspected that it was a result of the television exposure, but they were never able to apprehend a culprit.

If asked if we would do it all over again, I think Corry and I would reply with a resounding "Yes!" The emotional bond between us continues to grow stronger with each passing year. Despite the lack of legal status, we consider ourselves married in our eyes and in the eyes of our friends and family. Now that we have won the right to legally marry, we will go to get the little piece of paper. But recreate another ceremony? I think not. Okay, maybe a little celebration ...

\section{She Said}

We were married in an evening ceremony, filled with romance and gentility, surrounded by friends and family. The only word to describe it is "magical." The positive emotions and unconditional support were 
astounding to the point that for me, they were a tangible entity. I wasn't nervous but rather excited, as marrying Carla was the most 'right thing' that I had ever done in my life. The celebration afterwards was indeed the best that I had ever attended. Everyone was high on the joy and meaningfulness of the evening. Everywhere I looked people were smiling.

The ceremony itself was the culmination of much planning, consulting, and soul searching. It was in August that I asked Carla to marry me. As I remember it, I fumbled around the words "join me in a commitment ceremony" or "let's have a joining ceremony" or "would you commit to me?" Regardless, I loved this woman and wanted to let her know that it was important to me that I both share my love for her with our friends and family and ask them for their affirmation of our relationship in some sort of a special event.

We began telling people of our plans to have an*'event,' and what I noticed was that each time the words would vary slightly, as if they were not the right words and I was not privy to ones I wanted to use.

During a Christmas shopping expedition I found a book on the discount table of a local bookstore about the journey to the altar for two men. It seemed serendipitous to have found it. As it turned out, this highly emotional book provided clarity. These men had so many hurdles to get over in order to have their ceremony the way they dreamed it could be. At some point they decided that this joining was as important to them as marriage had been to their siblings. "Marriage," that seemed to be the operative word. Why couldn't they call it a wedding? And so they did.

After much discussion with Carla about the legitimacy of our relationship, I decided that I would begin to call this event "our wedding." I had already had a wedding, having once been married in a heterosexual union. This time neither the government nor the church, a cruelty that I continue to fight against, would sanction our union. I was going to call this "our wedding" because I could see no logical argument that would make me believe that my wanting to spend the rest of my life with Carla and to have that relationship given the seal of approval in front of our family and friends was any less real than the same beliefs and wishes of a heterosexual couple. It was not long before Carla was using the same terminology, telling me she also felt it important. 
So began the excitement and confusion and endless list of decisions needed to create a ceremony that would be what we had always wanted for a wedding.

We had to tell our children first. I have four children: Kelly (15), Jeremy (12), Ted (10), and Hilary (7), to whom Carla has become the other stable parent in their lives. At supper one night we began the discussion of our desire for a wedding, and asked for their feedback. My precious Ted, who is always thinking ahead of the game asked, "But Mummy, who's going to wear the wedding dress, and can I wear a tux?" Once we had all stopped laughing, it was decided that we would set our wedding for the evening and make it a formal event.

We began asking our friends for their input at our annual New Year's Day party. To our pleasure they were all extremely thrilled about our wedding. Along with the wedding came the excitement of dressing up, organizing a shower, and copious offers: "What can we do to help?"; "We want to be a part of this!" It seemed to mean a lot to them that we wanted, and indeed intended, to take part in what had traditionally been a heterosexual right. There was no assumption that our wedding would be steeped in all the other roles, posturing, and hierarchies often found in a heterosexual marriage.

The wording of our invitation seemed very important and took a great deal of time to agree upon. Why we stressed over it I am still pondering, as we sent the invitations out only to our friends and family, who all knew the depth of our love for each other.

The next step for Carla was to write a letter to her father, who was living in Denmark. Her relationship with her father (or, for that matter, the rest of her family) is distant. Her mother passed away over 20 years ago and, since Carla has no siblings, her father and two aunts are her only biological family. Needless to say I was aghast that she wrote a letter, included our family picture and said, "So Dad, this is my family." Nothing more, nothing less! "Is that all?" I asked, "No further discussion of who you are or how you came to this place?" "No need." And so it was that Carla relayed to her family that she was both lesbian and had this family of which she was an integral part.

To top it off, a month later Carla sent her father an invitation to our wedding. By this time I was going crazy. "Just like that?!" was my response. I guess, in retrospect, it came as no surprise that Carlo, 
Carla's father, called from Denmark one morning to tell me he was excited and on his way for the wedding. I called Carla at work to inform her that her father was on his way. "He's what?" came her response. When I think back on that moment I become quite emotional. This man, who saw Carla once every ten years or so, and wrote letters about 4 times a year, felt it important enough, real enough, and legitimate enough to make the long trek from Denmark at the age of 78 , for his daughter's wedding.

And so began the outpouring of love and support.

My family gathered from Toronto, Halifax, and Vermont. There was never a hesitation on their part to participate, just a clear assurance that this wedding was no less important than my previous one; in fact this one was more meaningful.

We met with Nancy, the minister of our church, the Unitarian Fellowship of Fredericton, to book the sanctuary and to ask that she perform the ceremony. She gave us many suggestions about what to include in the ceremony, and encouraged us to write the ceremony ourselves, to include what was important to us.

Unfortunately, she was waiting on a date for medical treatment and so asked us to consider a second person to perform the ceremony in the event that she was not available: "After all, you don't really need me, anyone could perform the ceremony." These words stick with me, as it was one of the most important details of my wedding. If I couldn't have my union sanctioned by the state I was at least going to have it performed by somebody who had the authority to marry two people. As it turned out, Nancy's treatment date came sooner than expected and, well on the road to recovery, she was thrilled to be able to be a part of our ceremony.

The details fell into place, including the issue of where to have the reception. A dear friend of ours offered her beautiful house, and we could not have been more grateful to her. We asked several of our dearest friends to read during the ceremony; the children embraced with enthusiasm the prospect of reading in front of the congregation; and one of our best friends agreed to give 'the toast to the brides.' Tuxedos were rented, dresses fitted, and new shoes purchased. All was set for a wonderful ceremony.

On the day of our wedding we awoke to the most brilliant, sunshiny day in March. What more could we ask for? We spent the day performing the last minute details and getting increasingly more 
excited. Flowers arrived at the house from friends unable to attend, accompanied by notes carrying loving encouragement and enthusiasm.

At last it was time to dress and make our way to the church. I was overcome with the positive vibrations and the fabulous karma that was being generated by the guests. The ceremony was far better than we had hoped. The minister had us sign a 'certificate' that she had created on her computer. This little piece of paper means more to me than anything else we received as wedding presents. She said that although she wished that the certificate were legal, she knew that our 'wedding' was as legitimate as any other she had performed.

Our children commented on the fact that Carla was now 'legally' their other mother and could they refer to her as such? This small act of innocence touched Carla deeply, although she had already been acting as their other mother.

The party raged on until the wee hours of the morning. People ate, drank, danced, and acted as if they never wanted the evening and the magic to end. Certainly I did not want it to end. Weeks later friends and family were still commenting on how much fun they had had and what a lovely evening it had been.

My relationship with Carla feels stronger and more secure than any other relationship I could imagine. We have based our union on values we hold with great fervor. Now that the government has finally legalized same-sex marriages, I will marry my darling again and accept the marriage certificate with PRIDE.

\section{Works Cited}

Dwyer, Victor. "NOT SO QUEER AS FOLK: Who Took the Fun, and the Fire, Out of Being Homosexual?" Maclean's. 23 Jun. 2003: 42.

Equality for Gays and Lesbians Everywhere (EGALE). "Ontario

Court of Appeal Unanimously Affirms: Same-Sex Couples Have Equal Right to Marry — Effective Immediately!” 10 Jun. 2003. $<$ http://www.egale.ca/banner.asp?item $=108 \&$ version=EN $>$.

Equality for Gays and Lesbians Everywhere (EGALE). "Same-Sex

Marriage Now Legal in B.C.!” 8 Jul. 2003.

$<$ http://www.egale.ca/banner.asp?item $=109 \&$ version=EN $>$. 
Galloway, Gloria. "Toronto North America's Gay Pride Capital." Globe and Mail. 30 Jun. 2003. <http://globeandmail.ca/servlet/ story/RTGAM.20030629.wgayy629/BNStory/National/>.

Sullivan, Andrew. "Here Comes the Groom. A Conservative Case for Gay Marriage." New Republic. 28 Aug. 1989. Rpt. 2002. <http://www.andrewsullivan.com/homosexuality.php>.

Tierney, William G. Academic Outlaws. Queer Theory and Cultural Studies in the Academy. California: Sage, 1997.

Wooley, Karen. Prod. "Episode 009." Weddings. Series 2. Life Network, Toronto. Jul. 1999. 